\title{
Agroforestry is promising for previously cleared hardwood rangelands
}

\section{Doug McCreary \\ Livestock grazing is the primary economic use of most hardwood rangelands in the coastal foothills of California. But owners of these lands may be able to increase revenues by simultaneously producing two crops, trees and sheep. In 1993, we initiated an agroforestry project at the UC Hopland Research and Extension Center to study the ability of three pine species and one hybrid to grow on cleared hardwood rangelands that are grazed by sheep. This study also evaluated the response of planted seedlings to auger and fertilization treatments. After 8 years, tree survival has been high, growth has been vigorous and damage from sheep minimal. Monterey pine and $K M X$ pine, a cross between Monterey and knobcone pine, had the most growth. These results suggest that some pine species are promising for planting on grazing lands in coastal foothills where oaks and other hardwoods have been removed.}

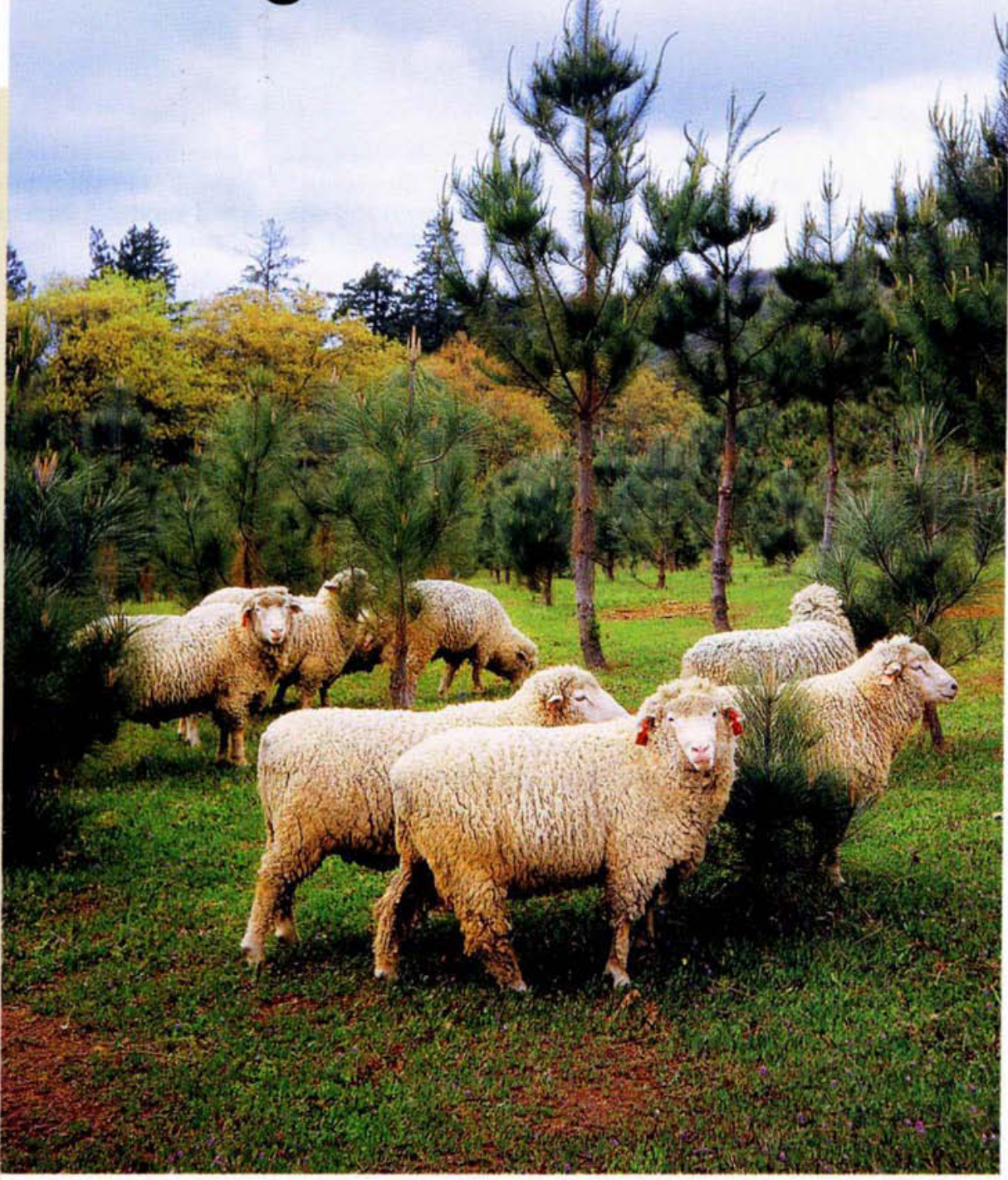

Grazing has been a primary use of California's hardwood rangelands, but economic returns are low. By combining tree farming with sheep grazing, producers may be able to increase their income while limiting the pressure to subdivide open space.

$80 \%$ of the hardwood rangelands in the state are in private ownership.

Since European settlement, the primary agricultural use of these lands has been livestock grazing, because they provide excellent forage for sheep and cattle. However, the returns from grazing are relatively low; these lands typically rent for only about $\$ 10$ to $\$ 20$ per acre per year. Low returns and fluctuations in meat and wool prices have created economic hardships for some ranchers. As the price of unde- veloped land escalates, ranchers have been under increasing pressure over the past decade to subdivide and convert large ranches to other uses such as ranchettes or vineyards. The public costs of such conversions are great. They include degradation of critical wildlife habitat, loss of soil stability, lessening of water quality and drastic alterations in the visual landscape. Concern about the accelerated rate of such conversions has resulted in public appeals for increased government 


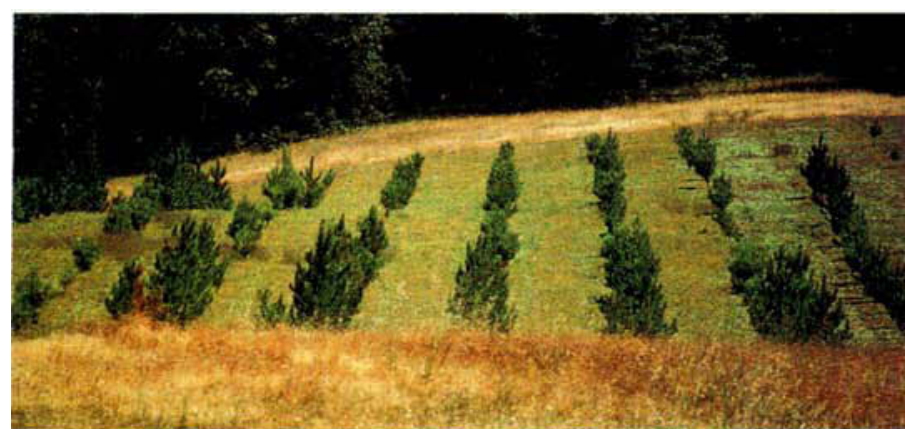

In a trial at the UC Hopland Research and Extension Center, three species of pine (Coulter, knobcone and Monterey) and one hybrid (KMX) were planted in 1993 and 1994, then grazed by

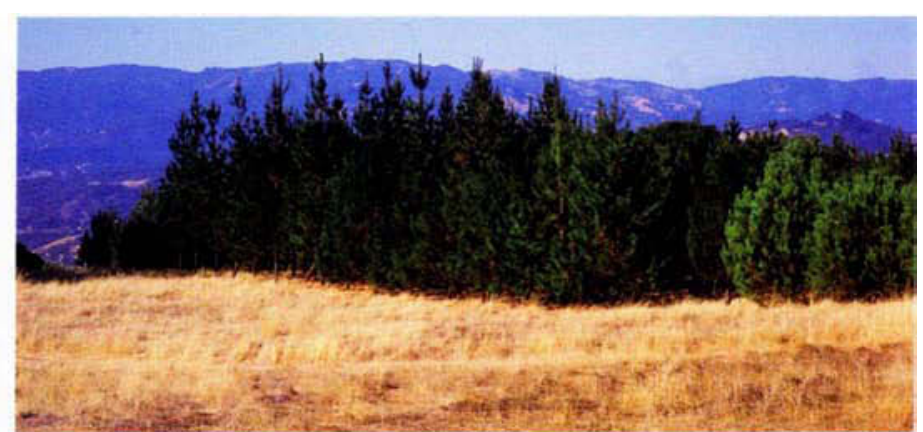

sheep after 1997 . Two years after planting, left, $81 \%$ of the trees had survived. By September 2001, right, the plot was full of mature trees. regulation of hardwood rangelands in hopes that further losses can be curtailed.

It may be possible to increase revenues from these grazing lands by simultaneously growing trees on them. While forest grazing is common in California, scientists have not seriously tested the establishment of plantations where trees and livestock are raised together on rangelands. However, such systems have been extensively - and successfully - used in New Zealand, Australia and elsewhere, primarily with Monterey pine (Pinus radiata) plantations and sheep grazing (Reid and Wilson 1985).

The most common trees on typical hardwood rangelands in California are native oaks, including coast live oak (Quercus agrifolia), blue oak (Q. douglasii) and interior live oak (Q. wislizenni). These species are tremendously important for a variety of reasons including wildlife habitat, soil stabilization, nutrient cycling and aesthetics. There is also widespread public interest in and support for oak conservation. However, native oaks generally grow slowly and have little economic value, other than for fire- wood. As such, they are poor candidates for use in an agroforestry system.

While the importance of maintaining existing stands of native oaks is well recognized, there are vast areas in the state where trees have been removed as part of range conversions, mostly since World War II (Bolsinger 1988). Small plots of these cleared grazing lands may be suitable for planting one or more species of conifers that can tolerate relatively harsh rangeland conditions, yet grow much more rapidly than oaks. Grazing could continue for a number of years until the canopies close and the lack of light limits the amount of forage produced. Tree crops could be used for a variety of products including pulp, lumber, biomass (fuel to power cogeneration facilities), Christmas trees or firewood.

While the markets for some of these products are not well established and returns may be low, some additional income is better than none, and intensive management can increase the value of the wood (Emmingham 1995). Also, although pine firewood doesn't burn as efficiently or fetch as high a price as oak, plantations established

TABLE 1. Average survival (\%) of pine species (averaged over fertilization and auger treatments) and auger treatments (averaged over species and fertilization treatments), 1994-1999*

\begin{tabular}{lcccccc}
\hline \hline Treatments & \multicolumn{7}{c}{ Year } \\
\hline Monterey & 1994 & 1995 & 1996 & 1997 & 1998 & 1999 \\
KMX (hybrid) & 94 & 91 & 90 & 90 & 86 & 85 \\
Knobcone & 89 & 86 & 85 & 85 & 84 & 83 \\
Coulter & 74 & 74 & 73 & 73 & 68 & 68 \\
Auger & 78 & 76 & 76 & 76 & 75 & 75 \\
No auger & $88 \mathrm{a}$ & $87 \mathrm{a}$ & $86 \mathrm{a}$ & $86 \mathrm{a}$ & $83 \mathrm{a}$ & $82 \mathrm{a}$ \\
Mean of survival & $79 \mathrm{~b}$ & $77 \mathrm{~b}$ & $76 \mathrm{~b}$ & $76 \mathrm{~b}$ & $73 \mathrm{~b}$ & $73 \mathrm{~b}$ \\
\hline
\end{tabular}

Auger and no auger treatments with different letters were significantly different by a Tukey's multiple comparison test. There were no significant differences in survival within species in any year.

for firewood could promote oak woodland conservation by reducing the demand for oak firewood. Additional income generated by these projects could also reduce the pressures to sell and subdivide rangeland. However, it has not been clear which conifers will perform well in rangeland environments and whether or not sheep can graze these lands without damaging trees.

In southwest Oregon, which has a climate similar to many hardwood rangelands in California, a hybrid between two native California conifers knobcone pine ( $P$. attenuata) and Monterey pine - has been successfully grown on lands grazed by sheep (Logan 1983). Monterey pine is native to only three small stands along the California coast and two islands off Mexico but has been planted extensively outside of California, especially in the Southern Hemisphere. It grows rapidly and can produce high-quality lumber if intensively managed.

Knobcone pine is also a California native, but it grows on much harsher inland sites, mainly in the northern coastal mountains. The hybrid between these two species, called KMX $(P$. attenuata $\times P$. radiata), has proved successful on some marginal lands because it incorporates the drought and cold tolerance of knobcone with the fast growth of Monterey pine (Griffin and Conkle 1967). Coulter pine ( $P$. coulteri), another California native, is also considered quite drought tolerant and produces wood comparable to that of ponderosa pine.

\section{Four tree species planted}

To evaluate how well Monterey, knobcone, KMX and Coulter pines 
grow on low-elevation hardwood rangelands, we initiated a study at the UC Hopland Research and Extension Center (HREC). HREC is typical of many woodlands in the Coast Range, and there was a large cleared field that was suitable for the planting. These four pine taxa (known hereafter as species) were planted within a 4-acre enclosure, fenced to exclude both sheep and deer. Two hundred and forty 1-year-old seedlings from each of the species were planted 10 feet apart in early February 1993. The California Department of Forestry Fire Protection Nurseries at Davis and Magalia produced the seedlings. Seed for the seedlings originated in California, except for the Monterey pine, which came from New Zealand.

The planting site is at an elevation of approximately 1,500 feet, gently sloping with a southwesterly aspect and gravelly loam soil. Average annual rainfall at this site is approximately 37 inches.

We divided the plot into six blocks, each containing four groups of 40 seedlings. Each group, which contained a single species, was randomly positioned within each block and arranged in eight rows of five seedlings. Each block had all four species, each of which was randomly distributed in that plot (first split). Within each of the eight rows, we tested four treatments: (1) an auger was used to bore 2-foot-deep, 6inch-wide planting holes in the ground, and a 21-gram fertilizer tablet was placed in the hole; (2) augering, but no fertilization; (3) fertilization, but no augering; and (4) no augering or fertilization.

Within each 40-seedling group, two adjacent five-seedling rows were randomly assigned to each of these treatments. On the perimeter of the plot, a row of buffer seedlings was also planted to ensure that all seedlings had the same level of competition from adjacent trees.

Holes were made with the auger and the soil was placed back in the holes 2 months prior to planting. The planting was done by hand using shovels and post-hole diggers. For the trees receiving fertilizer, we placed
Trees were planted with or without both an auger treatment and fertilization tablets, and none were irrigated. From 1997 to 1999 , lower branches were pruned to promote clear, knot-free wood.

slow-release 21-gram fertilizer tablets (20-10-5 nitrogen, phosphorous, potassium) approximately 10 inches deep in planting holes. The seedlings were never irrigated after planting. However, during the first 4 years of the study, we used herbicides, including glyphosate and pendimethalin, and we mowed to control weeds around seedlings. This was done to reduce soil moisture loss and eliminate habitat favorable to animals that could damage trees, including grasshoppers and voles.

Initial survival was high; 2 months after planting, only 12 of 960 trees had died. The first summer, however, we failed to mow until we noticed a grasshopper infestation; by fall, approximately $22 \%$ of the seedlings were defoliated and subsequently died. This defoliation was especially severe on the perimeter of the plot. We were concerned that the low initial survival would affect the data as the trees matured, because those trees surrounded by open spaces would have less competition than those surrounded by other trees. Also, because entire rows of seedlings had been killed, resulting in large data gaps, we decided to replant all the seedlings that died the first year with 1-year-old stock in winter 1994. While we kept records indicating planting year for each seedling, all of the results reported are averages for seedlings planted in both 1993 and 1994.

Maintenance. In early spring 1997 , we put sheep inside the fenced enclosure to graze the forage between the rows. They have grazed the plot every spring since. During these grazing intervals, sheep had equal access to all trees. When we first introduced the sheep, the average tree height in the plot ranged from approximately 12 feet for Monterey pine to about 5 feet for Coulter pine. The number of animals and length of grazing period each year varied depending upon an-

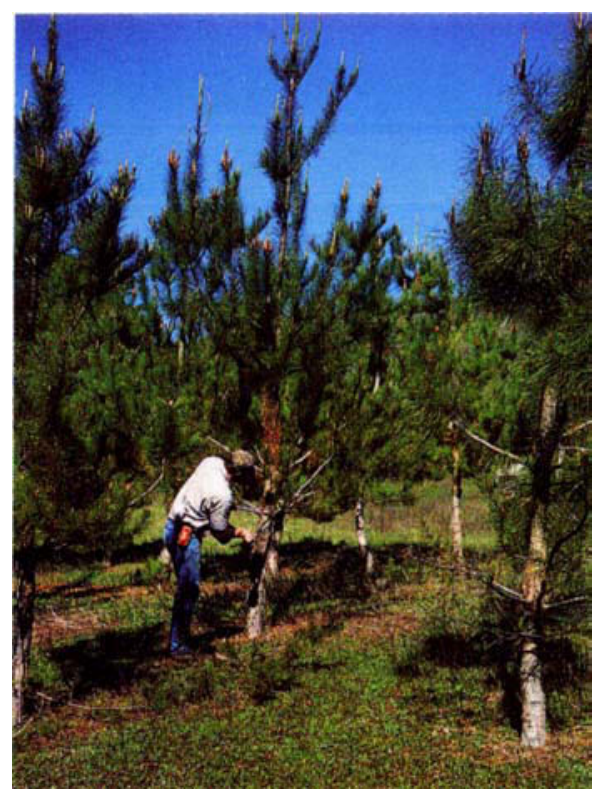

nual forage production, but on average, about a dozen sheep were kept in the plot for a month. We took care to monitor the animals and remove them before the forage was grazed down so much the animals might start chewing on the trees.

Beginning in 1997 and continuing for the next 3 years, we began pruning the lower branches off trees that were at least 10 feet tall. Such pruning is used to promote clear, knot-free wood, which is much more valuable (Emmingham 1995). In general we pruned the branches off the bottom half of the trees up to a maximum height of approximately 8 feet.

We measured the year-end height of each surviving tree in January or February of each year following the second year of planting. Average height measured at this time is reported as year-end height for the preceding year. Year-end survival percentages were also calculated.

\section{Tree survival and height}

The data for all analyses were averages of the two five-seedling rows consisting of single auger and fertilization treatments within species within blocks. The survival percentages were transformed by an arcsin transformation prior to analysis to normalize the data. The experimental design for the study was a doubly nested three-way ANOVA. Whenever we found significant differences among treatments, we compared treatment means using a 


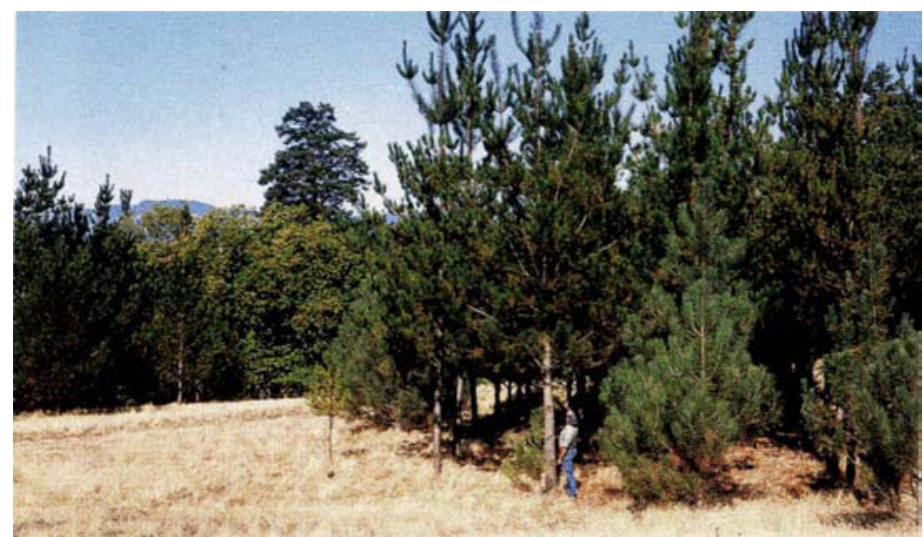

Less than 8 years after planting, many trees were more than 20 feet tall. The Monterey pine and KMX hybrid performed best, although pitch canker could be a risk, especially to Monterey pine.

Tukey's test. All results reported as significant were at the $P<0.05$ level.

As indicated previously, there was considerable mortality the first summer after planting, largely the result of grasshoppers. By the end of 1994, however, after we replanted all seedlings that died the previous winter, average survival was much higher and ranged from $74 \%$ for knobcone pine to more than $94 \%$ for Monterey pine. During the next 6 years, additional mortality amounted to only $6 \%$, and by the end of 1999 , the average survival rate for the entire planting was $78 \%$. For all years of the study, survival for different species was not significantly different, and there were no significant differences between fertilized and unfertilized plants (table 1). However, for each year (1994 through 1999), seedlings that had been planted in auger-treated holes had significantly higher survival than those without the auger treatment, with the differences ranging from $9 \%$ to $10 \%$ higher (table 1). But survival rates depended on the species: Knobcone pine seedlings without the auger treatment had higher survival than those with auger treatment, while the opposite was true for the other three species.

The average height of surviving seedlings at the end of 1994 ranged from 4.3 feet for Monterey to 1.7 feet for Coulter pine (table 2). In every year of evaluation, Monterey pines were the tallest, followed by KMX, knobcone and Coulter. In every year, Monterey pines were significantly taller than the other three species, and in all years but 1994, KMX was signifi- cantly taller than Coulter. By the end of 1999, the Monterey pines averaged over 23.5 feet tall, while the Coulters were only 10.7 feet.

There were no significant differences in height between seedlings that were planted in augered holes and those that weren't during any year of the study. However, there were height differences between fertilized and nonfertilized trees in each year, with fertilized trees significantly taller (table 2). In 1997, 1998 and 1999, Monterey pines that did not receive auger treatments were slightly taller than those that did. For the other three species, there was either no difference between auger and no auger treatments, or the seedlings in holes with auger treatments were slightly taller.

Sheep grazing resulted in little noticeable damage to the trees. In some instances, lateral branch tips were clipped, but no trees appeared to be killed by the sheep.

\section{Planting choices}

There were significant differences among the pine species evaluated. While overall survival rates among the species were similar, Monterey pine grew significantly taller than the others. This is consistent with a companion study of trees planted two years earlier at the Sierra Foothill Research and Extension Center (McCreary 1996). The advantage of Monterey pine, at least in terms of total height, also appears to increase over time. Average annual growth between 1994 and 1999 was nearly 4 feet, with some trees in individual years growing nearly double this rate. By the end of 1999, there were 26 trees (out of the 240 Monterey pines initially planted) over 30 feet tall.

KMX did not grow as tall as Monterey pine, but generally performed better than the other two species. Over the course of a tree crop rotation - about 20 to 25 years - KMX may be better suited to survive periodic droughts or unseasonable cold snaps than Monterey pine. Also, Monterey pine is reportedly particularly susceptible to western gall rust (Endocronartium harknessii), especially when planted outside its native range. Although the incidence of gall rust in this study was low (approximately 3\% of trees exhibited galls), it was three times more common on Monterey pine than on KMX pine.

The auger treatment resulted in significantly improved survival but did not affect growth. The gains in survival were noted the first year, but did not change thereafter. Apparently this treatment allowed plants to grow deeper roots immediately after planting, reducing mortality from desiccation, but once the trees were established - with or without auger treatment - their survival rates were not affected.

By comparison, fertilization resulted in significantly greater overall height in each year of the study, ranging from an average increase of $9 \%$ in 1999 to $18 \%$ in 1996 . Since the fertilizer tablets used in this trial cost only 5 cents per plant and did not add appreciably to planting costs, the gains in height from fertilization suggest it is well worth the cost for similar plantings in similar soils.

\section{Economic returns}

A critical question that must be answered before embarking on any large-scale planting of conifers on hardwood rangelands is, What are the likely economic returns from the trees? Clearly this will depend on a host of factors including distance to markets (for firewood, pulp or biomass), expected market prices, risk of crop loss from diseases and environmental events such as severe storms that blow down trees.

Such an analysis is beyond the scope of this paper, but some insights and valuable information about agroforestry systems throughout the world are available (Reid and Wilson 1985). However, potential markets are somewhat limited in California because so few landowners are planting 
trees, except in commercial forest situations. But as we have seen with the recent California energy crisis, things can change quickly. For instance, it may turn out that agroforestry products have a high value for energy if plantations are located near cogeneration facilities.

\section{Pitch canker}

A debilitating disease of Monterey pines called pitch canker, caused by the fungus Fusarium subglutinans, has raised concern about whether Monterey pine should be planted at all in California outside of its limited natural range. This pathogen was first discovered in the state in 1986, but it became a major concern just after our planting was established (Storer et al. 1994). While most virulent in Monterey pine, it infects a wide range of other pines and is reported to naturally infect all species tested in our study. Pitch canker has caused significant losses in Monterey pine Christmas tree plantations and has decimated the small remaining stands of native Monterey pine along the California coast. There is an additional fear that the disease could infect other more commercially important conifer species such as Douglas fir and ponderosa pine. This concern is heightened because in California, insects including bark and twig beetles are the major mechanism for the pathogen's spread (Storer et al. 1997). Since these insects have broad host ranges, insect vectors could result in expansion of the pitch canker's geographic range.

Although pitch canker has never been isolated from Douglas fir trees in their native range, it has been found on Douglas fir trees planted in an arboretum in Monterey County. Douglas fir is a tremendously important timber species in the western United States, and it is feared that the disease could spread inland or north through isolated plantings of Monterey pines or other suitable hosts, eventually infecting coastal and Sierran Douglas fir forests. The possibility of breeding varieties of Monterey pine that are genetically resistant to pitch canker is currently being investigated, but this could take years. Until resistant stock is produced or effective control methods developed, planting Monterey pine outside its natural range poses the risk of expanding the range of pitch canker.

\section{Promise of agroforestry}

Our study indicates that several pine species can survive and grow, at least initially, on unirrigated hardwood rangelands in California. Once the trees are established and several feet tall, the pastures they are planted in can be grazed by sheep with little damage to the trees, as long as the animals are removed before forage becomes limited. (Sheep will clip the shoots of conifer trees if there is nothing else to eat.) Auger treatments with 2-foot-deep holes prior to planting resulted in significant increases in survival, but had no effect on height growth. Fertilization, on the other hand, improved height growth by about $10 \%$ but had no effect on survival. Both treatments therefore appear to aid in the establishment of conifers planted on hardwood rangelands.

TABLE 2. Average height (feet) of pine species (averaged over fertilization and auger treatments) and fertilization treatments (averaged over species and auger treatments), 1994-1999*

\begin{tabular}{|c|c|c|c|c|c|c|}
\hline \multirow[b]{2}{*}{ Treatments } & \multicolumn{6}{|c|}{ Year } \\
\hline & 1994 & 1995 & 1996 & 1997 & 1998 & 1999 \\
\hline Monterey & $4.3 \mathrm{a}$ & $7.2 \mathrm{a}$ & $11.2 \mathrm{a}$ & $15.7 \mathrm{a}$ & $20.0 \mathrm{a}$ & $23.5 \mathrm{a}$ \\
\hline KMX (hybrid) & $2.5 \mathrm{~b}$ & $4.3 \mathrm{~b}$ & $6.9 \mathrm{~b}$ & $9.9 \mathrm{~b}$ & $13.2 \mathrm{~b}$ & $16.3 \mathrm{~b}$ \\
\hline Knobcone & $2.0 \mathrm{~b}$ & $3.4 \mathrm{bc}$ & $5.3 \mathrm{bc}$ & $7.5 b c$ & $10.6 \mathrm{bc}$ & $13.1 \mathrm{bc}$ \\
\hline Coulter & $1.7 \mathrm{~b}$ & $2.7 c$ & $4.2 \mathrm{c}$ & $6.1 \mathrm{c}$ & $8.3 \mathrm{c}$ & $10.8 \mathrm{c}$ \\
\hline Fertilized & $2.8 \mathrm{a}$ & $4.7 \mathrm{a}$ & $7.3 \mathrm{a}$ & $10.3 \mathrm{a}$ & $13.6 \mathrm{a}$ & $16.5 \mathrm{a}$ \\
\hline Unfertilized & $2.4 \mathrm{~b}$ & $4.1 \mathrm{~b}$ & $6.5 \mathrm{~b}$ & $9.2 \mathrm{~b}$ & $12.5 \mathrm{~b}$ & $15.3 \mathrm{~b}$ \\
\hline Mean of height & 2.6 & 4.4 & 6.9 & 9.8 & 13.0 & 15.9 \\
\hline
\end{tabular}

These results suggest that agroforestry systems using pines and sheep are promising on California's oak woodlands, especially for Monterey and KMX pines. However, more time is needed to evaluate the long-term survival and growth rates in these environments, and to determine if the potential benefits of such systems outweigh the risks of pitch canker and other diseases. We are continuing to study these issues.

D. McCreary is Area Natural Resources Specialist, UC Sierra Foothill Research and Extension Center, Browns Valley. The author thanks Jerry Tecklin for his assistance in all phases of this project; Laurie Lippet, Nursery Manager, California Department of Forestry L.A. Moran Reforestation Center, for rearing the seedlings; and Robert Keiffer and the staff at HREC for help with planting seedlings, weed control, measuring and pruning trees and herding the sheep used for grazing. Special thanks also to Dale Chapman and the Chapman Forestry Foundation for the generous gift that made this project possible.

\section{References}

Bolsinger CL. 1988. Hardwoods of California's Timberlands, Woodlands and Savannas. USDA Forest Serv Pac NW Res Stat Resource Bull PNW-148. $148 \mathrm{p}$.

Emmingham $W$. 1995. Pruning to enhance tree and stand value. Woodland Workbook. Ore State Univ Ext Serv. 12 p.

Griffin J, Conkle MT. 1967. Early performance of knobcone $\times$ Monterey pine hybrids on marginal timber sites. USDA Forest Serv Pac SW Range \& Exp Sta, Res Note PSW156. $10 \mathrm{p}$.

Logan R. 1983. Agroforestry: Growing trees, forage and livestock together. Ore State Univ Ext Circ 1114. 4 p.

McCreary D. 1996. An agroforestry system for California's hardwood rangelands. In: Ehrenreich JH, Ehrenreich DL, Lee DW (eds.). Proceedings, Fourth North American Agroforesty Conference: Growing a Sustainable Future; July 23-25, 1995; Boise, ID. p 135-7.

Reid R, Wilson G. 1985. Agroforestry in Australia and New Zealand. Goddard \& Dobson. $223 \mathrm{p}$.

Storer AJ, Gordon TR, Dallara PL, Wood DL. 1994. Pitch canker kills pines, spreads to new species and regions. Cal Ag 48(6):9-13.

Storer AJ, Gordon TR, Wood DL, Bonello P. 1997. Pitch canker disease of pines: Current and future impacts. J Forestry 95(12):21-6. 